\title{
RATE CONFERENCES IN THE RAILROAD INDUSTRY UNDER THE SHERMAN ACT AND THE ACT TO REGULATE COMMERCE
}

\author{
John Dickinson*
}

The Editor of Law and Contemporary Problems has asked me to contribute an article to this symposium with knowledge that I am engaged as counsel in a case now sub judice which presents for judicial consideration some of the questions to which the symposium is addressed. The practice of publicly discussing cases which are $s u b$ judice is one for which we doubtless have to thank the law reviews; but it has spread far beyond them. Lawyers who have made arguments and signed briefs for the United States Department of Justice and for the State of Georgia on the other side of the case which I have mentioned have broadcast books, articles, and speeches discussing the case, ${ }^{1}$ doubtless on the theory that they know more about it, and are, therefore, better qualified to inform the public, than commentators more remote from the controversy.

In spite of these examples, the present writer does not intend to discuss here the so-called Georgia case, nor those issues in it which he believes to be the controlling ones on which the decision should turn. There is, however, a legitimate field for public discussion of such cases in so far as they involve, aside from the special facts and issues peculiar to the case, broad matters of public policy which reach beyond any particular case, and on which public opinion needs to be informed. Thus there would seem no reason why a lawyer should refrain from discussing capital punishment because he is engaged in a murder case, or the question of the purity of the ballot because he is prosecuting election frauds. On the same principle, there are questions of public policy related to some of the issues in the Georgia case which are proper for public discussion without reference to the facts and issues peculiar to that case.

In the Georgia case, the plaintiff State charges a coercive conspiracy through the

* A.B. I913, Johns Hopkins University; A.M. 19r5, Ph.D. rgrg, Princeton University; LL.B. I92r, Harvard University. Vice-President-General Counsel, the Pennsylvania Railroad Company, and Professor of Law, University of Pennsylvania. Formerly Assistant Secretary of Commerce; Assistant Attorney General.

${ }^{2}$ See for example: Chapters II, 12 and I3 of Arnazl, The Shore Dimiy Seen (1946); pages 52-54 of Arne C. Wiprud's review of Arnall's book in 33 A. B. A. J. 52 (r947); chapters I-VI of WipnuD, JUstice in Transportatton (1945); pages 910-912 of Ellis Gibbs Anall's review of Wiprud's book in 54 YALE L. J. 9 Io (1945); chapters X-XIII of BERGE, Economic FREeDOM FOR THE WEST (1946); pages 127-128 of Wiprud's review of Berge's book in I4 U. of CH. L. Rev. 127 (1946); the entire article of Edward Dumbauld, Rate-Fixing Conspiracies in Regulated Industries, 95 U. of PA. L. Rev. 643 (I947). Governor Arnall, chief counsel for Georgia before the Supreme Court, appeared before the Senate Committec on Interstate Commerce in 1946 in the course of hearings on H.R. 2536 to testify "in behalf of the public," and not only took this occasion to argue Georgia's side of the case (Hearings before the Senate Committee on Interstate Commerce on H.R. 2536, 79th Cong., 2d Sess. 418-551 (1946)), but stated that if the Senate did not pass the bill then before it, he could state authoritativcly that Georgia would win the case. Id. at 435 . 
alleged use of rate conferences and associations by the defendant railroads, northern and southern, to charge rates which are said to discriminate against Georgia. ${ }^{2}$ In others words, the plaintiff charges that the rate conferences have been used for an improper purpose, and in ways that are wrongful and damaging to a particular state or section. The charge is thus one of abuse or misuse of the conferences. With that charge, which the defendant railroads contend is the proper and substantial issue in Georgia's case, and which she must prove if she is to prevail, this article will not deal, as the matter is one of evidence now under consideration by a special master appointed by the Court. ${ }^{3}$

Wholly apart, however, from these special averments and issues in the Georgia case, there remains a broad general question of antitrust law as to whether or not rate conferences in the railroad industry are in and of themselves, and without reference to any charge of abuse or discrimination, violations of the Sherman Act per se. This is a question of law and principle which can be discussed generally, and without specific reference to Georgia any more than to any other state or section of the Union. This discussion may appropriately lead up to the further question of whether there is anything inherent in the rate conferences, or in their procedures, which makes them necessarily discriminatory against any state or section.

It is a practice of fifty years' standing for the railroads of the United States in each of the historic territorial rate subdivisions ${ }^{4}$ to confer together about a proposed rate change before any railroad or railroads make the change by filing a tariff with the Interstate Commerce Commission. The usual course is for the proponent road to send notice of the proposal to the territorial association, which places it on a public docket that is given wide publicity among shippers. On a date therein specified, shippers are invited to appear and express their views with respect to the proposal.5 In this way, the railroads are informed in advance whether any shippers or communities assert rights under the Interstate Commerce Act that would be violated by the new rate, or claim that it would otherwise adversely affect them. With this in-

${ }^{3}$ Georgia v. Pennsylvania R. R., 324 U. S. 439, 445 (1945).

${ }^{3}$ Special Master Lloyd K. Garrison was appointed by order of the Court on December I7, 1945. See Georgia v. Pennsylvania R. R., 326 U. S. 693 (I945).

'The five major rate territories are official (northern) territory, southern territory, western trunk-line territory, southwestern territory, and mountain-Pacific territory. Official territory has three subdivisions, distinguished by their respective conference organizations which are as follows: New England Freight Association, Trunk Line Association, and Central Freight Association. See Justice Douglas' opinion in New York v. United States, 67 Sup. Ct. 1207, 121 I n. (1947), for a brief and lucid description of the boundaries of the major rate territories.

'See pages $43-45$ of Report on Rate-Making and Rate-Publishnng Procedures of Railroad, Motor, AND Water Carriers, submitted to the President and Congress on Nov. 24, 1943, by the Board of Investigation and Research, acting pursuant to section 302 (b) of the Transportation Act of r940. This document, which was printed as H. R. Doc. No. 363,78 th Cong., Ist Sess (1943), and which is hereinafter cited as Report on RATE-Making Procedures, includes at pages 4I-50 a detailed discussion of the jurisdiction, membership, organization, and procedure of railroad rate burcaus. It is pointed out at page 43 that under typical procedure, shippers, shippers' organizations, other railroad associations, and Government departments may also submit proposals directly to the bureau. 
formation before them, a committee of representatives of the railroads of the territory discusses the proposal; and each road, as a method of expressing its views, votes whether or not the proposal should be "recommended." If the matter is contentious, it may be "appealed," i.e., brought for further discussion before committees consisting of higher officers of the railroads. Irrespective of the "votes" in the different committees, the proponent railroad may at any time, and frequently does, put the

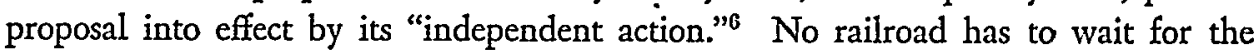
proposal to pass through the different committees, if it does not wish to do so.

The available statistics show that the vast majority of proposals are disposed of by correspondence without requiring discussion in any of the committees, and that the number of so-called "appeals" is very small. Any railroad is free to by-pass the conference procedure altogether with respect to a rate proposal, but that procedure is usually followed as an almost indispensable method of ascertaining what effect the proposal would have on shippers and other railroads, which have a legal interest under the Interstate Commerce Act in the rates that affect them. ${ }^{\text {? }}$

A large proportion of railroad rates, including most of those which give rise to controversy, are so-called "joint through rates" between origins and destinations not reached by the same railroad, and which therefore require the participation of two or more connecting roads. ${ }^{8}$ Often the connecting roads, whose concurrence is necessary to establish the rate, are located in different rate territories. Thus, a joint through rate between Atlanta, Georgia, and Buffalo, New York, requires the concurrence of a railroad or railroads like the Southern, the Seaboard, and the Louisville \& Nashville, which belong to the Southern Rate Association, and the Pennsylvania, Baltimore \& Ohio, and New York Central, which belong to the rate associations in northern territory. Obviously, a proposal to change such a rate must be concurred

\footnotetext{
o "Appeals" and "Independent Action" are discussed at pp. 46-47 of the Report on RATE-MAKino Procedures.

${ }^{7}$ In 1923 the Commission, recognizing this importance of the conference method to shippers as well as to carriers, said in its report in Trans-Continental Freight Bureau, 77 I.C.C. 252, 278:

"Witnesses for shippers as well as for respondents testified that the bureau's method of advising shippers of proposed tariff changes was of great value to them, and that the bureau procedure providing for presentation to the standing rate committee, either orally or in writing, of shippers' views before that committee makes its recommendation, gives them an opportunity to show the cffect that a proposed rate change would have upon them and thereby prevent any undue advantage to a competitor. This procedure provides for an interchange of views which usually leads to rates satisfactory to shippers, and thus removes occasion for their suspension when published, and for the resulting expenses to both shippers and carriers of formally presenting the case before us."

Sce also pp. 260, 27x, 277. This report summarizes the facts found and conclusions reached by the Commission after investigation, pursuant to SEN. RES. No. 194, 67th Cong., 2d Sess. (1921), of the operations of the Trans-Continental Freight Bureau. The Bureau, similar in organization, procedure, and functions to most rate bureaus, was found to promote economy and efficiency, to be of advantage to shippers and carriers, and to fill the need for group consideration of proposed ratc changes (77 I.C.C. 252, 279). The proceeding was dismissed, without dissent.

See also: Report on Rate-Making Procedures, at 85, where the Board of Investigation and Research records its conclusion that rate bureaus and conferences "serve a purpose that is necessary to the conduct of the business and to the public regulation of carriers"; Smith, Ratc-Making and the Anti-Trtst Latu, I2 I. C. C. PRACT. J. III7, II25, II27 (1944-45).

${ }^{8}$ See "Interterritorial Rate-Making," Report on Rate-Making Procedures, 47-50. Some rate burcaus deal solely with interterritorial rate adjustments.
} 
in by both the southern and northern participating connections-neither is entitled to compel the other to accept the new rate. The proposal is, therefore, discussed in the associations of both territories. If the original proponent is one of the southern connections, it submits the proposal in the first instance for consideration in the Southern Association, after which it is sent for consideration by the northern connections through one or more of the northern associations. Here also there is complete right of independent action, and if a southern proponent of a joint through rate to a northern destination can obtain the necessary concurrence of a northern connection reaching that point, the rate can be at once filed with the Commission on behalf of these two railroads, if they so desire, without regard for the attitude of any other southern or northern road, and without the necessity of waiting for their concurrence if they do not choose to give it. However, for reasons that will be explained later, independent action in such a case would be practically certain to precipitate litigation before the Commission.

Almost all the proposals submitted for discussion in the rate associations are for rate reductions. ${ }^{9}$ This is inevitable, as rate increases are now almost entirely confined to those which result from decisions of the Commission in so-called "general rate cases." Of the proposals for rate reductions which are considered in the conferences, all but a small percentage are ultimately made effective in filed tariffs. Where the proposals involve joint through rates which must be participated in by connecting carriers in two separate rate territories, the number which fail to be made effective is somewhat greater and runs in the neighborhood of 15 per cent. In these cases there is, of course, always the opportunity, as in the case of all rate proposals, for any shipper or railroad dissatisfied with the result to take the matter before the Commission on its own initiative and obtain the proposed reduction by Commission order, if the Commission regards the existing rate as too high or as in any way unreasonable or discriminatory.

Sometimes, where an existing rate adjustment which would be affected by a rate proposal is so complicated and widespread that the proposal cannot be satisfactorily handled between the rate associations of two or more territories by correspondence, a special conference of the railroads in the different territories is held to consider the series of changes which the proposal would entail. Such conferences are ad hoc affairs and are called from time to time when proposals are made which would require extensive changes in the interterritorial rates on such important articles of traffic as citrus friut, iron and steel, textiles, chemicals, paper, and the like, which are produced and marketed in a number of different sections of the country. In these ad hoc conferences, as in the regular association committees, each railroad preserves its full right of independent action, and the railroads of one rate territory are not bound by the decisions of those of another territory, although, of course, neither can compel the other to concur in any proposal. In recent years the mechan-

\footnotetext{
${ }^{\circ}$ For example, see the statistics set forth in Trans-Continental Freight Bureau, cited supra, note 7,
} at $27 \mathrm{r}$. 
ical details of these ad hoc conferences have generally been arranged through the Association of American Railroads, one of whose officers, after consultation with the interested parties, sets the date and place of the meeting, sends out the notices, and distributes the minutes. In general, the Association itself is not and has never been a forum for the consideration of rate matters. In only three instances during a period of twelve years has the Association's Board of Directors expressed itself with respect to any particular rates, and in two of those instances the roads involved promptly took independent action at variance with the Association's recommendation. ${ }^{10}$

Beginning in Ig28, the Interstate Commerce Commission called on the railroads of the different rate territories to make wholesale readjustments in the interterritorial rates on a large number of commodity groups. ${ }^{11}$ This necessitated such constant conferences and negotiations between the connecting lines in the different territories, whose participation in the new rates was necessary, that a more or less permanent machinery for the conduct of such conferences was set up to last until the task should be completed. This was the so-called "Joint Conference of Contact Committees,"12 consisting of representatives of the railroads in the different rate territories, which met periodically and took up, one after another, the commodity groups covered by the Commission's orders. In these conferences, as in the special conferences mentioned above, each railroad preserved, and frequently exercised, its right of independent action, and the railroads of one rate territory were not in any way bound by the votes of those in other territories.

It is apparent from this review that neither the territorial rate associations nor the interterritorial conferences fix or otherwise determine the rates which are to be filed by any railroad with, the Interstate Commerce Commission, nor do they have any power to prevent a rate from being filed if the railroad or railroads over whose rails the rate is to apply decide to file it. The conferences embody no agreement on the part of the member roads to charge any particular rates, or to abide by any rates, or to refrain from changing any rates. The territorial associations are simply clearing houses through which notice of rate proposals is given and orderly consideration accorded to them by the interested shippers and railroads. ${ }^{13}$ The interterritorial conferences serve the same purpose with respect to the broader rate adjustments in which the railroads and shippers of several sections of the country are involved. The con-

${ }^{10}$ Report on Rate-Making Procedures, at p. 28, includes a specific statement of A.A.R. activities. The three exceptional instances of A.A.R. action concerning rates were:

(I) Resolution of December 18, 1936, concerning rates on copper bullion, ignored by independent action of the Denver \& Rio Grande Railroad and the Western Pacific Railroad;

(2) Resolution of January 18, 1935, concerning rates on grain, ignored by independent action of southern railroads;

(3) Resolution of October 30,1936 , concerning rates on citrus fruit.

${ }^{11}$ Southern Class Rate Investigation, roo I.C.C. 513 (I925), order becoming effective Jan. 15, 1928;

Rates, from, to, and between Points in Southern Territory, I91 I.C.C. 507 (I933).

${ }^{12}$ Report on Rate-Marung Procedures, cited supra, note 5, at 49.

13 Trans-Continental Freight Bureau, 77 I.C.C. 252, 260-261, 270, 278 (r923); REpoRT ON RATEMaking Procedures, cited supra, note 5, at 28, 46-47; Smith, loc. cit. stipra, note 7, at 1125-I127. 
ferences do not enable some railroads, or any railroad, to veto the rates charged or proposed to be charged by another, except, of course, that a road which wishes to change a joint through rate participated in by a connecting line or lines cannot make the change effective if its connections are unwilling. This would be true whether the rate conferences existed or not.

The function and value of the rate conferences is to develop information and afford opportunity for discussion. As will be explained later on, such information and discussion are needed, because practically every railroad in a given rate territory is to some extent a partner with every other in joint through rates, and this is even more true with respect to the railroads in adjacent territories. If a rate reduction is proposed which would apply only on certain railroads or over a particular route, the shippers located on those railroads or on that route would be given an immediate advantage over shippers located on competing routes, contrary to the provisions of the Interstate Commerce Act. Such discrimination would at once give the disadvantaged shippers a cause of action before the Interstate Commerce Commission. It therefore becomes essential for a railroad, before putting a new rate into effect, to know whether it would give rise to such a charge of discrimination in order to determine whether to carry out the proposal, or so modify and extend it as to remove the objections. Generally no single railroad is in a position to have at its disposal all the necessary factual data for a determination of these questions, such as information concerning the location of industries, the markets reached by shippers on competing lines, and the like. It is the function of the rate conferences to develop such information for the benefit of all their members and to provide a forum for the discussion of proposals in the light of such information.

In some instances the discussion among the railroads which goes on through the rate conferences may lead a railroad which has proposed a rate reduction to take a different view of the matter from that which it took before it had all the facts at its disposal; while in other instances the information made available may eliminate opposition to the reduction on the part of those who were at first opposed to it. Discussion and enlightenment may work either way, and there can be no doubt that in some instances a reduced rate, which would have been filed in a tariff with the Commission but for the discussions in the conferences, is not filed after that discussion has taken place. However, as stated above, any shipper or railroad which is dissatisfied with such a result can bring the matter at once before the Commission for its determination.

Because of the full and complete right of independent action which exists in the rate associations and conferences; because of the power of the Interstate Commerce Commission to correct rate inequities and protect the public generally and particular shippers from unreasonable and discriminatory rates; and finally because the discussions in the conferences have been regarded as practically indispensable in assisting the railroads to conform their rates to the detailed requirements of the Interstate Commerce Act, as will hereafter be explained, it was for long not supposed that the 
rate conferences and associations involved any violation of the antitrust laws. Within the last few years a contrary view has emerged, and has not only found reiterated expression in many books, articles, and speeches emanating from persons connected with the Antitrust Division of the United States Department of Justice, ${ }^{14}$ but has also been interjected into antitrust suits brought purportedly on other grounds. This view appears to rest on two underlying conceptions. The first is the abstract and formal one that under the antitrust laws any discussion or exchange of views and information between competitors about prices, before putting those prices into effect, is per se prohibited, and that this prohibition extends to the railroads in spite of the obvious fundamental differences between railroad rates, under a system of regulation, and unregulated prices in the manufacturing and commercial industries. The second basis for the view appears to be a conception that shippers are lawfully entitled to anything which will bring about a rate reduction for their benefit below the rates fixed as reasonable by the Interstate Commerce Commission, and that, since in some instances the railroads, after discussion and consultation through the conferences, fail to put into effect proposed reductions, the conferences are thereby rendered unlawful as depriving shippers of something to which they are by law entitled. The general question of whether conference and discussion among the railroads before filing their rates with the Interstate Commerce Commission is a violation of the antitrust laws will now be discussed.

II

Solely for the purpose of the present argument, it may be conceded that in an unregulated commercial industry, like those engaged in the production and distribution of oil, automobiles, tobacco, fertilizer, and the like, any discussion between competitors in advance of prospective price changes, even though not accompanied by an agreement upon prices, or any other form of "price-fixing," might conceivably be held to constitute an unlawful interference with the kind and degree of free competition in those industries which is required by the antitrust laws. In the light of the decisions up to this time, it is not believed that there is any general rule of antitrust law which, apart from special circumstances, would require this result. ${ }^{15}$ However, that is not the question here. Here the question is whether, assuming that such might be the rule of law for the unregulated industries in question, the same legal result must necessarily follow, or can reasonably be held to follow, for an industry like the railroad industry, whose prices, or "rates," are subject to the degree and

\footnotetext{
${ }^{14}$ For example, see: publications of Berge, Wiprud and Dumbauld, cited supra, note I; numcrous speeches of Thurman W. Arnold, such as those reprinted in Rxp. Proc. GA. BAR Ass'N 135-152 (194I); 12 Míss. L. J. 579-588 (I940); I2 Mo. B. J. I74-178 (I94I); Arnold's introduction to Wiprud, Justicy in Transportation (1945); statements of Messrs. Annold, Wiprud, and other representatives of the Division in Hearings before the Senate Committee on Interstate Commerce on $S .942,78$ th Cong., Ist Sess. 5, 69, 89, 97, 123, I77, I82, 203, 213, 24I, 287, 353,454, 458,46I, 470, 5Ir, 535, 584, 651, 770, 78 r (I943).

16 Thus, in the Sugar Institute case, the Supreme Court held that it was not unlawful for competitors to exchange information as to future prices so long as there was no agreement to adhere to such prices. Sugar Institute v. United States, 297 U. S. 553, 603 (I936).
} 
kind of regulation imposed on them by the provisions of the Act to Regulate Commerce. In other words, the question is whether railroad rates, which are subject to all the legal requirements and restrictions of the Interstate Commerce Act, that do not apply to unregulated industrial prices, are at the same time also subject to all the requirements with respect to prices which are imposed on the unregulated industries by the antitrust laws.

There is no doubt that the railroads do not enjoy any general immunity from the prohibitions of the antitrust laws. ${ }^{16}$ However, on the particular point here under discussion, the question is the narrower one of whether the antitrust laws impose exactly the same prohibitions with respect to conferences about railroad rates that they do, or might be held to, impose with respect to prices in industries not subject to a comprehensive Congressional system of rate regulation. It is well settled that the antitrust laws do not impose a code of identical prohibitions against exactly the same acts in all situations and circumstances. What the antitrust laws do or do not prohibit is generally dependent on surrounding facts. As the Supreme Court has said, "A close and objective scrutiny of particular conditions and purposes is necessary in each case. Realities must dominate the judgment.... The question of the application of the statute is one of intent and effect, and is not to be determined by arbitrary assumptions."17

In this connection it is further to be noted that one of the most important surrounding facts relating to the railroad industry is that it is subject to the Interstate Commerce Act. Where an industry like the railroads is subject not only to the antitrust laws, but also to the Interstate Commerce Act, the provisions of the antitrust laws in their application to the railroads must obviously be given such construction as not to be inconsistent with the requirements of the Interstate Commerce Act, and not to defeat the latter. The two statutes must be read together, and each so construed that its requirements will not have the effect of destroying the other, nor of making compliance with its specific terms and provisions impossible or impracticable. There can be no doubt that it is the Interstate Commerce Act in which Congress has specifically embodied its policy and scheme of regulation for the railroads. The provisions of that Act are at once detailed and comprehensive, and it is not to be supposed that Congress intended that those provisions, most of which have been enacted long since the date of the Sherman Act, should be overridden, superseded, or defeated by the construction given to the extremely broad and vague language of an earlier statute, as construed in cases dealing with private industries for which Congress has provided no such scheme of regulation as it has established for railroad rates. ${ }^{18}$

${ }^{10}$ United States v. Trans-Missouri Freight Association, 166 U. S. 290 (I897); United States v. Joint Traffic Association, I7x U. S. 505 (I898); Terminal Warehouse v. Pennsylvania R. R., 297 U. S. 500, 515-516 (1936); Georgia v. Pennsylvania R. R., 324 U. S. 439, 456, 457, 458, 462-463 (1945).

${ }_{17}$ Appalachian Coals, Inc. v. United States, 288 U. S. $344,360-36 \mathrm{r}$ (1933). See also Maple Flooring Association v. United States, 268 U. S. 563, 579 (I925); Sugar Institute v. United States, 297 U. S. 553, $597,600(1936)$.

${ }^{18}$ McLean Trucking Co. v. United States, 321 U. S. 67, 79, 83-84 (1944). 
Accordingly, in determining whether a prohibition imposed by the antitrust laws with respect to prices in unregulated industries is intended by Congress to apply also to the railroads, whose rates are regulated by the detailed requirements of the Interstate Commerce Act, it is essential to determine: (I) whether the reason for that prohibition, and the policy on which it is founded, exist where a comprehensive Congressional scheme of rate regulation is present, or on the contrary are incompatible with the regulatory scheme or with the policy which it embodies; and (2) whether the application of the prohibitions in question to the railroad industry would impair effective compliance with the specific requirements of the Interstate Commerce Act.

On the first of the foregoing points it is relevant to inquire whether the Interstate Commerce Act indicates a Congressional policy with respect to competition in railroad rates different from the policy embodied in the antitrust laws with respect to price competition in unregulated industries. If in the latter industries the Sherman Act should be held to prohibit all discussions about prices among competitors, this prohibition, since it is not expressly stated in the language of the Act, but proceeds only from construction, cannot be assumed to flow from arbitrary considerations, but must have its source in some policy and purpose supposed to be embodied in the statute. This policy and purpose must therefore be examined to determine whether it is identical or consistent with the policy and purpose embodied in the Interstate Commerce Act with respect to competition in railroad rates.

If the Sherman Act is to be construed as prohibiting all discussions about prices among competitors, the supposed Congressional policy on which such a construction would have to be founded is that which the Supreme Court has expressed in condemning under the Act "any combination that tampers with price structures."10 This supposed policy of the Sherman Act is that, for the protection of the public against unduly high prices, prices must be made solely by the free and unhampered operation of competitive forces, and anything which prevents prices from being solely the resultant of these forces must therefore be regarded as prohibited. Does the Interstate Commerce Act indicate, or is it consistent with the view, that in the railroad industry Congress has adopted the same policy of requiring that railroad rates shall be made solely by the free and unhampered operation of competitive forces?

In explaining this supposed policy of the Sherman Act with respect to the unregulated industries, the Supreme Court, speaking through Mr. Justice Stone, in its opinion in the Trenton Potteries case, ${ }^{20}$ found as a reason for the policy that there is no way to determine that a price is reasonable for the public except by the fact that it results from the unfettered operation of competition, since there is no way in which a court can satisfactorily determine for itself the intrinsic reasonableness of a price. It is at once obvious that this reason for the rule can have no application to railroad rates, since Congress has expressly provided a method for determining the reasonableness

\footnotetext{
${ }^{20}$ United States v. Socony-Vacuum Oil Co., 310 U. S. I50, 22 I (1940).

${ }^{20}$ United States v. Trenton Potteries, 273 U. S. 392, 396, 398 (1927).
} 
of such rates by setting up the Interstate Commerce Commission to make such determinations. In other words, in the case of railroad rates Congress has not provided that reasonableness is to be determined according to whether or not they have been produced by the free operation of competitive forces. On the contrary, Congress has substituted for competition another and different method to provide the public with reasonable railroad rates. It has here substituted the judgment of an expert body for the operation of competition as the test and protection of rate reasonableness. To this extent Congress itself has directly interfered with, and limited, the free operation of competition in the field of railroad rates. Accordingly, in so far as competition in rates is permitted by law to operate, it is evident at the outset that in a most important respect it is only a limited and restricted kind of competition.

The most cursory inspection of the Act to Regulate Commerce discloses that by numerous provisions of that Act the free operation of competition in railroad rates is restricted in other important ways:

First, by the requirement of the Act that railroad rates must be "reasonable" as found by the Commission, such rates are prevented from rising to the level to which they might, and certainly would at times, be driven by the forces of free competition. Under free competition, prices must, and will at times, rise to levels of very high profits in order to counterbalance other periods of depressed prices, which have the effect of causing marginal producers to close down operations, if not actually go out of business.

Second, the Interstate Commerce Act expressly provides that railroad rates, to satisfy the statutory standard of reasonableness, must be adequate to provide the railroads with sufficient revenue to enable them to perform an efficient national transportation service. ${ }^{21}$ This standard of rate reasonableness is inconsistent with the philosophy of free competition as a regulator of prices. Under that philosophy, it is the normal expectation that prices will at times be driven down to very depressed levels, which will force many plants out of business and cause them to be dismantled, ${ }^{22}$ thus reducing the number of competitors for the time being and bringing about an increase in prices, perhaps to unduly high levels, which will attract new units into the business. The object of the Interstate Commerce Act is to protect the national transportation plant for the service of the public and preserve its com-

\footnotetext{
${ }^{21}$ Section 15a(2) of the Act is as follows: "In the exercise of its power to prescribe just and reasonable rates the Commission shall give due consideration, among other factors, to . . . the need, in the public interest, of adequate and efficient railway transportation service at the lowest cost consistent with the furnishing of such service; and to the need of revenues sufficient to enable the carriers, under honest, economical, and efficient management to provide such service." $4 \mathrm{I}$ STAT. 488 (I920), as amended, 49 U. S. C. $\$ 15 a(2)$ (1940).

${ }^{22}$ Cf. Clair Wilcox, Competition and Monopoly in American Industry 2 (TNEC Monograph 2I, 1940): "Investment must be speedily withdrawn from unsuccessful undertakings and transferred to those that promise a profit. ... There must be no obstacle to elimination from the market; bankruptcy must be permitted to destroy those who lack the strength to survive." Again, "Failure in business curtails the supply of unwanted goods." Id. at 13.
} 
ponent railroads as going concerns. ${ }^{23}$ To this end the standard of rate reasonableness provided by the Act excludes not only those rate reductions which would cause the rails of necessary transportation lines to be torn up, but also those which would make it difficult or impossible to obtain additional increments of needed capital.

Third, the provisions of the Interstate Commerce Act depart from the basic philosophy of free competition in prescribing as a rule of law complete rate equality between all persons and places similarly situated. Further to enforce this equality, the Act requires that rate changes shall go into effect only after published notice and a waiting period of thirty days, ${ }^{24}$ so that one customer may not be benefited by a rate reduction which could be immediately withdrawn so as to deprive other customers of the opportunity to take advantage of it. This kind of over-all equality in rates for all purchasers of railroad service who are similarly situated would not be produced by the operation of free competition, but is in fact inconsistent with, and contrary to, the results that free competition is relied on to bring about. ${ }^{25}$ Just as the free play of competitive forces operates by successive swings between destructively low prices and prices which yield high profits, so it operates through charging different prices to different customers for competitive reasons. This is not permitted under the Interstate Commerce Act.

Fourth, the Interstate Commerce Act requires the establishment and maintenance of such relationships between the rates to and from different places as to prevent unjust inequality of opportunity for different shippers seeking to reach the same markets. In other words, under the Act, the rates which may lawfully be charged to a user of the service located at one point must bear such a relationship to the rates charged to users elsewhere that, after taking into account legitimate differences in transportation conditions as found by the Commission, neither group of users will be unfairly advantaged or prejudiced as compared with the other. ${ }^{20}$ This again is a result wholly different from that which the free operation of competitive forces would bring about, or is in theory expected to bring about. Under free com-

\footnotetext{
${ }^{23}$ In the railroad industry there is no such thing as withdrawal of capital or abandonment of the field in the sense in which those opportunities exist in an unregulated industry. Under section $I$ ( $I 8$ ) of the Interstate Commerce Act, no carrier may abandon all, or any portion, of a line of railroad, or the operation thereof, without having first obtained from the Interstate Commerce Commission a certificate of public convenience and necessity authorizing the abandonment. 24 STAT. 379 (1887), as amended, 49 U. S. C. $\S I(I 8)(1940)$. Under section I (20), any abandonment without such certificate is made punishable by fine of not more than $\$ 5,000$, or imprisonment for not more than three years, or both. 24 STat. 379 (I887), as amended, 49 U. S. C. \$I(20) (I940).

${ }^{2}$ Such an arrangement for advance publication of future rates and adherence thereto, which in the case of the railroads is required by law, is precisely the kind of arrangement that is illegal under the antitrust laws in an unregulated industry. See United States v. American Oil Co., 262 U. S. 371 (1923); Sugar Institute v. United States, 297 U. S. 553, 6or (1936).

${ }^{25}$ EDwin R. A. Seligman, Principles of Economics 150 (1914): "The very essence of usual business practice is this system of different prices to different customers." See also Fly, Observations on the -Antitrust Laws, Economic Theory and the Sugar Institute Decisions, 45 YALE L. J. 1339, 1347 (1946).

20 "To upset or seriously to menace a general rate structure lawfully established suffices to make proposed rates calculated to effect such a disruption unreasonable and unlawful." Trunk-Line and Ex-Lake Iron Ore Rates, 69 I.C.C. 589 .(1922). See also Grain and Grain Products, II5 I.C.C. I53 (1926); Ex-Ohio River Coal to Ohio Points, 185 I.C.C. 211 (1932).
} 
petition the seller of a commodity or service, in making prices to his different customers, is not required or expected to take into account anything but what will result in immediately attracting to him the largest volume of business, irrespective of the effects on the comparative positions of his customers among themselves.

Fifth, the Interstate Commerce Act prohibits railroads from discriminating between their different connections. ${ }^{2 \pi}$ The problem of connecting lines, as it exists in the railroad industry, is something that has no parallel in the manufacturing or marketing industries. In the latter industries, one concern is not necessarily and mechanically dependent on another to complete its service. It can get its goods into the hands of its customers directly or through an intermediary of its own choosing, or, if it so desires, can refrain altogether from serving customers at any particular place or in any section of the country. This is not true of a railroad. It cannot limit its service to its own line. It must be prepared to accept shipments to points which can be reached only over the rails of other railroads. So-called through routes and joint rates are thus necessary, and in performing such joint service each road is dependent upon the cooperation of its connections. There is the added peculiarity that two roads may stand in the position of competitors and connections at the same time. Thus the Baltimore \& Ohio and the Louisville \& Nashville are competitors between St. Louis and Cincinnati while they are connections with respect to traffic between St. Louis and points south of Cincinnati. Under the Interstate Commerce Act a railroad is not free to limit itself to a particular connection, as a manufacturer is free to choose a particular distributor of his products. The Pennsylvania must connect at Chicago with all the different railroads extending westward from that point to the Pacific Coast, and each of those railroads must, in turn, connect at Chicago not only with the Pennsylvania, but also with all of its competitors in the East. The Interstate Commerce Act embodies in its requirements the philosophy of a national transportation system. ${ }^{28}$ It provides that a railroad must open its rails to business from all its connections equally, including those which are its own competitors as well as those which are not. Thus the railroads constantly find themselves in the position of having to negotiate rates with their competitors, and these rates must all be equal between the same points of origin and destination.

Sixth, as an added means of insuring that each railroad will treat its connections equally, and thereby promote the free functioning of a national transportation system of separate roads, the Interstate Commerce Act expressly provides that in the case of

${ }^{37}$ This prohibition is contained in section $3(4)$ of the Act. 24 STAT. 380 ( 1887 ), as amended, 49 U. S. C. $83(4)(1940)$.

${ }_{28}$ c"The railroads of the country constitute a connecting and interlacing system of lines over which freight cars of all ownerships circulate freely. . .." Testimony of the Honorable Joseph B. Eastman, in Hearings before the Senate Committee on Interstate Commerce on S. 942, 78th Cong., Ist Sess. 830 (1943). "Today it is recognized that the railroads of the country together form a single transportation system. Joint operations are on the whole of more importance than local operations. Trains or cars move freely from one railroad to another, and through routes and joint rates exist in multitudinous quantity. However, the single system is still made up of a large number of parts which are separately owned and managed. ..." The Honorable Joseph B. Eastman, in First Report of the Coordinator of Transportatton, Sen. Doc. No. irg, 73rd Cong., 2d Sess. 8 (r934). 
through routes the shipper, and not the originating railroad, is entitled to designate the connections over which the shipment shall reach its destination. ${ }^{20}$ To this end, all through routes are available to shippers to choose from, and a through route may not be closed over the protest of a shipper without the permission of the Commission. $^{30}$ This requirement, as well as those of equal treatment between connections, carries with it the necessary consequence that rates over all routes between the same points must be equal, ${ }^{31}$ since the charging of a higher rate over any route would be a practical method of closing that route to the shippers who desire to use it. Accordingly, a railroad desiring to change a rate over one of the through routes in which it participates must assure itself that the change can be effected over the other through routes between the same or related points to which it is likewise a party, since if it did not do so, it might find itself in the position of either closing a through route or discriminating against a connection and thereby violating the Act.

It is perfectly obvious that never in a million chances would the blind interplay of competitive forces succeed in producing a rate that met all these requirements of law. ${ }^{32}$ There seems to be a conception in certain quarters, including the Department of Justice, that all that the Interstate Commerce Act requires is that rates shall be at, or below, the reasonable maximum set by the Commission in its rate orders, and that beneath that level rates are supposed to stand at any point to which they may be driven by the operation of free and unhampered competition among the railroads in an effort to take business from one another.

This might be so if the only provision contained in the Act were that which empowers the Commission to set reasonable maximum rates and provides a penalty for disobedience to its orders. This, however, is only one among the many statutory provisions to which railroad rates are required to conform. The other and additional requirements summarized in the preceding paragraphs show that to meet all those requirements rates almost always have to stand at a different point from that which would be the resultant of the free and unhampered operation of competitive forces.

${ }^{29}$ Interstate Commerce Act, section I5 $_{5}(9)$ and section 15 (10). 24 STAT. 384 (I887), as amended, 49 U. S. C. $\$ I_{5}(9)$ and $15(10)$ (1940).

${ }^{30}$ Interstate Commerce Act, section $\mathrm{r}_{5}(3), 24$ STAT. 384 (1887), as amended, 49 U. S. C. $515(3)$ (I940).

${ }^{31}$ See the statement of the late Joseph B. Eastman in Hearings before the Senate Commitice on Intertsate Commerce on S. 942, 78th Cong., Ist Sess. 830 (I943): "It is also true that there is a great interdependence between rates. Where there is more than one route between two points, as a practical matter the rates must ordinarily be the same over all the routes. Even in the case of rates from widely separated origins to a common market, a change in one of the rates may impel changes in them all. $A$ change in the rate basis on one commodity between certain points may even force changes in the rates on other commodities between different points."

${ }^{32}$ The fact that a railroad set a rate at a particular point for competitive reasons is no defense to the charge that the railroad has violated the Act by publishing a rate which under some provision of the Act is unreasonable or unduly prejudicial. United States v. Illinois Central R. R., 263 U. S. 515, 525 (1924). See also Interstate Commerce Commission v. Inland Waterways Corporation, 319 U. S. 67 r, 685 (I943). In United States v. Chicago, M., St. P. \& P. Ry., 294 U. S. 499, 506 (1935), the Supreme Court, in referring to the limits upon a carrier's freedom of action in fixing its rates, specifically mentioned avoiding "rivalry so keen as to be a menace to the steady and efficient service called for by the statute," and cited section 15 a of the Act as the source of this particular restriction. 
If, beneath the reasonable maximum level set by the Commission's orders, rates were fixed solely by blind competition among the railroads for business, practically every rate so fixed would violate the Interstate Commerce Act in one or another important particular, and would therefore lead directly to a litigated case before the Commission, brought by some injured party to enforce his rights under the Act. Such a case would begin with a suspension of the rate, followed by long drawn-out legal proceedings to the discomfiture and expense of all parties concerned.

It is therefore plain that Congress, by its enactment of the detailed provisions respecting rates which are now a part of the Interstate Commerce Act, has not intended that ordinary commercial competition shall operate freely in the making of railroad rates. Instead it has substituted a list of statutory standards to which the railroads are required to conform in making their rates, and has empowered the Commission to police the application of these standards to prevent violations. These standards are in the first instance made binding by the Act upon the railroads themselves, which are supposed to do what they can to comply with them, just as individuals generally are supposed to make an effort to obey the law; while the Commission, as the policing agency, to avoid being swamped, is expected to have to deal only with the relatively exceptional cases of violation. ${ }^{33}$ From this it follows as a necessary consequence that Congress does not intend that the railroads in filing their rates with the Commission shall be guided by the purely competitive considerations which the antitrust laws require of sellers in an unregulated commercial industry. It is furthermore plain that Congress has not only not adopted the policy of requiring that railroad rates shall be made solely by the free and unhampered operation of competitive forces, but has instead prescribed standards for such rates which cannot be satisfied by rates that are made solely as the result of competition.

In the light of this obvious and necessary conclusion, we are now in a position to recur to the question, raised at an earlier point in this paper, as to whether the

\footnotetext{
${ }^{3 a}$ Some of the positions expressed by the Department of Justice assume that the railroads are not free to confine their competition by their own acts within the limits prescribed by the Interstate Commerce Act, but must in all instances wait to be compelled to do so by specific orders of the Commission. This is directly at variance with several provisions of the Act, and more specifically section 8 , which is as follows: "In case any common carrier subject to the provisions of this chapter shall do, cause to be done, or permit to be done any act, matter, or thing in this chapter prohibited or declared to be unlawful, or shall omit to do any act, matter, or thing in this chapter required to be done, such common carrier shall be liable to the person or persons injured thereby for the full amount of damages sustained in consequence of any such violation of the provisions of this chapter." 24 STAT. 382 (1887), as amended, 49 U. S. C. $\$ 8$ (1940). Thus, in the absence of an order of the Interstate Commerce Commission, a railroad may incur liability under this section by changing a rate in a way that violates some applicable provision of the statute. Bacr Bros. v. Denver \& R. G. R. R., 233 U. S. 479 (1914); Louisville \& N. R. R. v. Sloss-Sheffield Co., 269 U. S. 217 (r925). Accordingly, Chairman Aitchison, in testifying before the Committee on Interstate Commerce of the United States Senate, has said: "If in the initiation of any rate or charge the carrier's judgment as to what is just and reasonable, or as to what is a nondiscriminatory or nonpreferential practice proves to be wrong when tested in subsequent proceedings before the Commission, it is liable for the full amount of the damages suffered. . . " Hearings before the Senate Committee on Interstate Commerce on H. R. 2536, 79th Cong., 2d Sess. 1197 (1946). The Commission has, therefore, held that when carriers initiate rates they must apply the same standards that are applied by the Interstate Commerce Commission when it is subsequently called upon to pass upon the legality of the rates. Anadarko Cotton Oil Co. v. Atchison, T. \& S. F. Ry., 20 I.C.C. 43 (Igro).
} 
policy of Congress with respect to railroad rates is the same as that which, in the application of the Sherman Act to unregulated industries, might be held to prohibit all discussions and conferences among competitors about prices. It was there pointed out that such a prohibition could be derived only from a supposed policy that prices must be made solely by the free and unhampered operation of competitive forces, and that anything which prevents prices from being solely the resultant of those forces must therefore be regarded as prohibited. It is now clear, in the light of the specific Congressional enactments with respect to railroad rates, that Congress has expressly repudiated that policy with respect to such rates and has substituted an entirely different one. Since the application of the Sherman Act to a particular industry must, under the universally accepted rule of construction, take account of the relevant facts peculiar to the industry and the Congressional intent with respect thereto, there remains no basis for holding that the Sherman Act in its application to the railroad industry must be construed or can properly be construed to prohibit conferences and discussions between railroads concerning rates.

\section{III}

The problem with respect to rates which confronts the railroads under the Interstate Commerce Act is how to make rates which will conform to the statutory standards. We have just seen that in the light of those standards it is clear that Congress does not intend railroad rates to be made by the free play of competitive forces, and that accordingly there is no basis for holding that consultation and conference in the making of railroad rates are prohibited by the Sherman Act. On the contrary, the requirements with respect to rates which are imposed by the Interstate Commerce Act are such that the railroads can comply with them only by conscious, deliberate effort. In this effort consultation and conference are necessary as a practical matter. In view of the nature of the rate standards established by the Act, and in view of the peculiarity of the railroad industry-that it consists of an interlaced nationwide physical plant owned and operated by many different companies, but made up of a network of joint through routes-it seems clear that in countless instances compliance with the rate standards of the Act is possible only after joint consideration and discussion by many different carriers concerning the course of action which they will take with respect to rate proposals. This conclusion was clearly and strongly expressed by the late Commissioner Eastman in the following words:

I do not know how the carriers can comply with the mandates of the law and the orders of the Commission unless they consult and confer with each other. ... It must be evident to any reasonable man that the carriers cannot respond to all the duties imposed by law if each carrier acts in a vacuum. It is a situation, under all the conditions, which plainly calls for consultation, conference, and organization and for many acts of a joint or cooperative character. ${ }^{34}$

\footnotetext{
${ }^{34}$ Hearings before the Senate Committee on Interstate Commerce on S. 942, 78th Cong., 1st Sess. 878,83 r (1943).
} 
It would be impractical, for lack of the necessary space, to illustrate this conclusion by reference to all the different types of rate proposals and rate relationships to which it applies. It is, however, desirable and important to point out the necessity for conferences between all the competing railroads in one rate territory and all the competing railroads in another territory whenever a proposal is made for a rate change between a point in one territory and a point in the other that are linked together by joint through routes in which all or most of the railroads in each territory participate. An illustration of this necessity is afforded by considering a proposal to reduce a joint through interterritorial rate from a point in the South like Atlanta to a northern destination like Buffalo. This illustration will show why the consideration of such a proposal by rate conferences consisting of all the railroads in the North and in the South is indispensable. It will at the same time disclose the confusion to which the prohibition of such conferences would lead, without conferring any compensating benefit on either shippers or the public.

Let us suppose, then, that the Southern Railway wishes to propose a reduction in the joint through rate on an article from Atlanta to Buffalo. Under the present practice the proposal is reviewed by all the southern railroads in their association to determine whether they will all join in it, and is then given similar joint con-. sideration in the association of the northern roads. What would be the result if this practice had to be abandoned and each road had to negotiate rate changes separately with each of its individual connections? If the rate conferences were abolished and the latter method adopted, the Southern would have to confer in the first instance with a single northern connection, say the Pennsylvania, to secure its concurrence in the proposed rate. Assuming that the latter were willing to concur, the Southern would then file with the Commission the new rate for account of itself and the Pennsylvania, and the tariff would be published on the usual statutory notice of thirty days. Within a few days after such publication, this action would doubtless come to the attention of other interested railroads and shippers. Thereupon, the Baltimore \& Ohio, for the protection of consignees located on its rails at Buffalo, would undoubtedly demand that the Southern agree to publish the same rate to Buffalo over its through route with the Baltimore \& Ohio north of Potomac Yard, in order to comply with that provision of section 3 of the Interstate Commerce Act which prohibits a railroad from discriminating between connections. Also, the Baltimore \& Ohio would undoubtedly insist that the rate via its line should be published so as to become effective not later than the same effective date as that designated for the rate filed in connection with the Pennsylvania, on the ground that otherwise consignees on its line at Buffalo would be discriminated against. Since, however, some time would have already elapsed since the original publication of the tariff by the Southern and the Pennsylvania, it would not be in the power of the Southern to bring about this equality of effective date. Application would therefore have to be made to the Commission to grant what is called "special short-term permission" for the new rate over the Baltimore \& Ohio. 
If it be assumed, as would almost certainly be the case, that other shippers of similar articles at Atlanta were located at that point on the rails of the Seaboard and the Atlantic Coast Line, and would insist on their right under the Act to be kept on a rate parity with Atlanta shippers located on the Southern, then the Seaboard and the Coast Line would each separately have to approach first the Pennsylvania and afterwards the Baltimore \& Ohio, requesting that each of the latter lines join in making the new rate available over the routes of the Coast Line and the Seaboard to the junction of the latter with the northern roads at Potomac Yard.

About this time undoubtedly the New York Central, which has connections with the South at Cincinnati but not at Potomac Yard, would approach the Southern and insist that the latter apply the same rate from Atlanta to Buffalo through the Cincinnati gateway in connection with the New York Central as through the Potomac Yard gateway, in order that the former route might not in effect be closed. This presumably the Southern would be willing to do. This, however, would prompt the Erie, another northern carrier having a line from Cincinnati to Buffalo, to demand a similar rate in connection with the Southern via the Cincinnati gateway.

Pursuing the illustration to its next stage, account must be taken of the fact that probably the Louisville \& Nashville also serves an Atlanta shipper or shippers of the article on which the rate is to be reduced, and will naturally desire to protect the right of such shippers to be kept on a parity of rates with other competing Atlanta shippers. Accordingly the Louisville \& Nashville, which reaches the Cincinnati gateway, would request the New York Central to join it in establishing the new rate via that gateway to Buffalo. Thereupon the Louisville \& Nashville would have to negotiate separately with the Erie, the Baltimore \& Ohio, and the Pennsylvania to publish the rate via Cincinnati in connection with each of their own lines from that point to Buffalo.

In the meantime, competing shippers of the same article at Birmingham, Alabama, which is served by the Louisville \& Nashville, the Southern, the Seaboard, and the Coast Line, would demand of all these railroads that the rates from Birmingham to Buffalo be proportionately changed so as to preserve their existing relationship with those from Atlanta to Buffalo. To this the Birmingham shippers are entitled under the Act. If the rate conferences were abolished, each of these railroads would have to handle this request separately. If the Louisville \& Nashville should conclude to establish the new rate requested from Birmingham to Buffalo, this would also require the Illinois Central to publish the same rate via its northern junctions at Chicago and Indianapolis, and this railroad would therefore have to undertake separately to secure the concurrence of each of its northern connections at these junctions. The northern lines as a group could not consider the request of the Illinois Central together as they now do, but the latter would have to deal separately and successively with the New York Central, the Nickel Plate, the Wabash, the Erie, the Pere Marquette, the Grand Trunk, the Baltimore \& Ohio, and the Pennsylvania. 
I have mentioned only a few of the many through routes between Atlanta and Buffalo and related points which carriers and shippers would be entitled under the Act to have kept on a rate parity. Even as to this limited number of routes the statutory thirty-day period (between the date when the new rate is first filed over the joint route of the Southern and the Pennsylvania and the date when that tariff would become effective) would leave far too short an interval for all the separate conferences that would have to be held between individual southern and northern connecting lines. Accordingly, since the establishment of the rate over any one route earlier than over another would result in prohibited discrimination against shippers located on the latter route, and might also discriminate against connecting railroads, it would be inevitable that petitions for suspension of the proposed rate would be filed with the Commission in order that the new rates from all related points of origin over all the usual routes might go into effect simultaneously. It would be inevitable that the Commission would grant the suspension and order a hearing. At this hearing, which would be at least thirty days after the suspension, the carriers and shippers would present their respective positions. Probably most of these would not represent any objection to the original proposal, but only insistence that, if the reduction should be made, it should be applied over all existing routes equally, and that corresponding reductions in other rates should likewise be made to preserve existing rate relationships prescribed or approved by the Commission.

The only result of such a procedure would be to bring before the Commission in the form of a litigated case practically every proposal for a rate change between important origins and destinations where any considerable number of through routes are available. This would be the result even if there were no substantial difference of view among railroads and shippers with respect to the proposed change. The litigation would provide the only legitimate means for getting all the interested parties together, which is now accomplished through the rate conferences. Ordinarily all the railroads involved in through routes are willing to join in a proposed change if it is extended to enough points to take care of all the routes in which they are involved, and to give the benefit of the proposed advantage equally to all the interested shippers along their lines. However, it is necessary for them to be in a position to assure themselves, as they now do through the rate conferences, that this will be the case. In such instances litigation before the Commission would be a futile expense and burden upon railroads and shippers alike.

There is of course a relatively small proportion of cases where some or all of the carriers in one or the other of the two rate territories would refuse to concur. Under the present conference method this fact emerges practically at once. The nature and scope of the objections can then be given consideration, with at least the possibility that a way may be found to meet the objections by some modification of the proposal. If the rate-conference method were abolished, and negotiations had to be limited to a series of successive discussions between separate and insulated pairs of connections, none knowing the position taken by the others, it would be 
impossible to determine before litigation whether an adjustment could be reached or not. If a southern railroad should be able to obtain a northern partner for a change which it desired in a joint through interterritorial rate to the North, while other northern roads opposed the change, then obviously the latter would go to the Commission and institute a suspension proceeding to protect the existing rates. This is done today wherever the conference procedure fails to produce agreement, and one pair of connections is willing by independent action to make a rate effective which the carriers that participate in competing through routes are unwilling to meet. At present, however, because of the conferences, a railroad does not have to go to the Commission until it is fully convinced of the necessity of doing so, as a result of its knowledge of the position of the other roads acquired through the conference procedure.

If that procedure were abolished and its place taken by a series of successive separate conferences between connections, a road would generally go to the Commission without fully knowing the position of the other roads that it was challenging, and might well find after the proceeding before the Commission had commenced that the controversy could be settled by a relatively minor change in the scope of the proposal. The conference procedure affords a method for making such mutual understanding possible in advance, and for working out solutions on which the parties can agree without the necessity of resorting to litigation. If the conferences should be abolished as unlawful, the result would be that wherever several joint routes existed, practically all adjustments of rates over any one of these would have to be worked out as a part of, and in the course of, litigation. From this no real advantage would result, but on the contrary the outcome could only be complication, delay, and expense for all concerned. Under the present method, the time and effort of the Commission are saved for cases where its services are really needed because the parties themselves cannot work out solutions for their conflicting claims. At the same time, it seems unnecessary to add that, under the conference method as it exists today, any shipper who is dissatisfied by failure to obtain a rate reduction which he desires is always free to take his case to the Commission, and the conferences are thus never able to deprive any shipper of the reasonable and nondiscriminatory rates to which he is entitled by law.

It is apparent from the foregoing review of a practical case such as occurs almost daily in the field of rate proposals that interterritorial rates between points in two different rate territories cannot be practically or promptly made or changed without consultation among all of the competing railroads in each of the two territories. This is because each railroad in one territory is a partner of all the competing roads in the adjacent territory, and is not allowed to treat them differently. Accordingly, a southern road which is a partner of all the northern roads must, before putting into effect a joint rate with any one of them, find out the postion of the others. To attempt to do this separately rather than through a single conference would introduce wholly futile and useless complications into the process. In the same way each 
northern railroad is a partner of all the southern competing lines, and must, before putting into effect a rate with any one of them, inform itself as to the position of the others. The only practical and convenient way of effecting these interchanges is through the rate associations of the two territories. If each railroad in one territory could only deal one at a time with those in the other territory, it would be impossible ever to agree upon joint through interterritorial rates which would meet the statutory standards; all such rates would have to be established through the cumbrous and expensive processes of litigation.

\section{IV}

A suspicion has been created by those opposed to the rate conferences that somehow, if all the railroads in one rate territory are permitted to confer simultaneously with all their connections in another territory in the manner described above, such consultation necessarily produces discrimination against the territory of a railroad which proposes a rate reduction. This is the ground on which it is suggested that Georgia and the South have an interest in demanding that the rate conferences should be outlawed under the antitrust laws. The argument is that if all the railroads in one rate territory, e.g., the North, are permitted to consider together a proposal for a rate reduction received by them from one or more of their connections in another territory, e.g., the South, the former will be more likely to find reasons for refusing to concur in the proposed reduction than if each northern road were compelled to reach its decision separately and in isolation, and without knowing what the other northern roads would do. Thus it is said that the practice of consultation through the rate conferences has a tendency to discourage rate reductions that might otherwise be made.

It is then further suggested that anything which discourages or impedes rate reductions from the South to the North (but apparently not from the North to the South) discriminates against the South. This suggestion is founded on the fact that admittedly certain rates between the South and the North, including the class rates and certain commodity rates, are or have been on a higher mile-for-mile level than rates in the North, although many other northbound interterritorial rates on important southern products are at or below the northern mileage level. It is suggested that while these higher southern rates are obviously not discriminatory in the sense prohibited by the Interstate Commerce Act, since in many cases they have actually been prescribed or approved by the Commission, nevertheless in some sense it is "discriminatory" against the South to follow any practice, such as the rate-conference procedure, which might possibly discourage, or interpose any obstacle to, their reduction.

This argument, which is conceived for the purpose of inspiring the South with opposition to the rate conferences, rests on a radical repudiation of the policy and philosophy of rate regulation embodied in the Interstate Commerce Act, and also upon what can only be described as a tragic failure to perceive and understand the true interests of the South. 
The suggestion that it is somehow discriminatory to refuse to reduce rates which are higher, mile for mile, than rates on like articles between other points, even though the higher rates are not themselves discriminatory under the Act, involves a complete failure to understand the provisions of the Act with respect to discrimination. Under the Interstate Commerce Act, as at common law, rates are not discriminatory merely because they happen to be on a higher mileage level than rates on the same article between other points. ${ }^{35}$ The Interstate Commerce Act creates no such arbitrary yardstick of discrimination, which, if adopted, would require that rates should be on the same mileage level between all points in the United States irrespective of traffic and transportation differences. Any such requirement would totally disrupt the commerce of the country. Under the Interstate Commerce Act departures from arithmetical rate equality are justified by what are known as differences in transportation conditions, including differences in the cost of transportation in the different rate territories due to building costs, operating costs, differences in traffic volume, and the like. ${ }^{36}$ Whether such differences in transportation conditions actually exist as to justify arithmetical differences in rates is obviously not a matter which can be determined by the free operation of competition, but only by the judgment of some expert body. Accordingly, the Interstate Commerce Act confers on the Commission exclusive jurisdiction to determine what rates are discriminatory and what are not. ${ }^{37}$ It would be completely disruptive of the unity and effectiveness of regulation under the Act if it were now held that there is some other kind of discrimination, different from that prohibited by the Act, which the railroads commit by charging rates on different mileage levels even where those rates have the sanction of Commission approval. This would, however, be the necessary consequence of holding that it is illegally discriminatory for the railroads to engage in rate con-

\footnotetext{
${ }^{35}$ In a long line of decisions, the courts have held that the provisions of sections 2 and 3 of the Interstate Commerce Act do not require a uniform level of rates and charges, and that the Act does not prohibit arithmetical differences in rates, nor all discriminations and preferences, but only those that are undue, unjust or unreasonable. Interstate Commerce Commission v. Baltimore \& O. R. R., I45 U. S. 263, 276 (1892); Manufacturers Ry. v. United States, 246 U. S. 457, 481 (19r8); Nashville Ry. v. Tennessee, 262 U. S. 3I8, 322 (I923); United States v. Illinois Central R. R., 263 U. S. 515 , 521 (I924); Board of Trade v. United States, 314 U. S. 534,546 (1942); Barringer \& Co. v. United States, 319 U. S. I, 6, 13 (r943).

${ }^{30}$ The courts have held that, in determining whether a particular arithmetical difference in rates constitutes an undue, unjust or unreasonable discrimination, the standard to be applied is a "transportation standard," that is to say, a standard derived from an examination of the conditions under which the transportation service is to be performed. This was stated by Mr. Justice Brandeis in the following language: "To bring a difference in rates within the prohibition of section 3 , it must be shown that the discrimination practiced is unjust when measured by the transportaton standard. In other words, the difference in rates cannot be held illegal, unless it is shown that it is not justified by the cost of the respective services, by their values, or by other transportation conditions." United States v. Illinois Central R. R., 263 U. S. 515, 524 (1924). See also Texas \& Pacific Ry. v. United States, 280 U. S. 627, 638 (1933). And see I. L. Sharfman, The Interstate Commerce Commission III-B, 685-687 (1936).

37 "It is not disputable that from the beginning the very purpose for which the Commission was created was to bring into existence a body which from its peculiar character would be most fitted to primarily decide whether from facts, disputed or undisputed, in a given case preference or discrimination exsted." White, C. J., in United States" v. Louisville \& Nashville Ry., 235 U. S. 314, 320 (1914). Sce also Manufacturers Ry. v. United States, 246 U. S. 457 (j9r8).
} 
ferences, because these might have the effect of interposing an obstacle to the reduction of a rate that is on a higher mileage level than some other rate.

Not only does the argument now under discussion ignore and repudiate the policy of the Interstate Commerce Act with respect to what constitutes discrimination, it also contravenes the policy of the Act with respect to rate reductions. That argument assumes that under the antitrust laws shippers are legally entitled to progressive reductions in railroad rates, below the reasonable maximum fixed by the Commission, to the lowest point to which such rates can be driven by the free and untrammeled operation of competition. This view in turn presupposes that Congress has adopted for railroad rates a policy, based on the postulate of free competition, that, even though prices at times sink to levels so low as not to be remunerative, this condition promotes the public interest and should accordingly be enforced by law. Of course, Congress has not done this; the Interstate Commerce Act embodies the opposite philosophy. As has been pointed out above, the Act prescribes as one of the standards of rate reasonableness that rates must be adequate to yield revenues sufficient to enable the carriers, under honest, economical and efficient management, to provide an adequate national transportation service. ${ }^{38}$ In other words, the rates to be reasonable must be remunerative.

Accordingly, it is simply not true that shippers are entitled by law to competitive rate reductions below the reasonable maximum rates established by the Commission. They are only entitled to rates which are reasonable under the standards prescribed by the Act, and not to any other kind of "reasonable" rates. There cannot be two legal standards governing the reasonableness of rates any more than there can be two legal standards for the determination of what constitutes discrimination. In both instances, the only legal standard possible is that which is prescribed by the Act, and the Act does not permit competitive rate reductions below the level of reasonably remunerative rates.

While the Interstate Commerce Commission since r 920 has been in a position to prevent the reduction of rates to unreasonably low levels by exercising its power to issue so-called "minimum-rate orders,"39 it is not true that, in the absence of such an order by the Commission, shippers are entitled to any reduction, however great, that free competition would bring about. The question of whether a proposed rate reduction would make the resulting rate unduly low is one which, under the Act, goes not merely to the exercise of the Commission's minimum-rate power, but is also an element in the statutory standard determining the reasonableness of the rate. If the effect of the reduction would be to make the resulting rate unduly low, then that rate, irrespective of any minimum-rate order issued by the Commission, would be unlawful under the Act as not conforming to the prescribed standard of reasonableness, and the Commission has frequently so held. In passing upon the

\footnotetext{
${ }^{38}$ Interstate Commerce Act, section 15a(2). 4 I Srat. 488 (1920), as amended, 49 U. S. C. \$15a(2) (1940).

${ }^{30}$ Interstate Commerce Act, section r5(I). 4I STAT. 484-488 (r920), as amended, 49 U. S. C. §15(I) (1940).
} 
power of the railroads to reduce their rates to meet competition the Commission has repeatedly said that such reductions, to be lawful, must not make the resulting rates unreasonably low. 40

It is, therefore, obvious that even if the rate conferences should have the effect of discouraging rate reductions in certain instances, they would not thereby necessarily deprive shippers of any rates to which the latter are lawfully entitled, nor would they necessarily contravene the policy of the Interstate Commerce Act. On the contrary, in so far as the conferences serve, by informing the judgment of the carriers, to aid them in avoiding those competitive reductions which are unreasonable and, therefore, unlawful under the Act, they affirmatively promote the policy of the Act and assist the railroads in conforming to its prohibition against unreasonably low competitive rates. For the latter purpose, consultation and conference are indeed indispensable, since, in order to determine whether a rate is unreasonably low by the standards of the Act, it is not sufficient merely to determine whether the rate is compensatory for the particular railroad which proposes to put it into effect; it must also be tested by comparison, with related rates that are applicable over other railroads and competing routes to determine what effect the proposed reduction would have upon the earnings of all the carriers interested in the particular rate adjustment. ${ }^{41}$ That the Act so requires has been repeatedly held by the Commission with the approval of the courts.

Thus, in Ex-Lake Iron Ore from Chicago to Granite City, the Commission said:

Plainly we are justified in condemning a rate on the ground that it is unreasonably low, where it is shown that it will cause loss rather than gain to the publishing road or roads and will thus impose a burden upon other traffic. In suspension proceedings, in view of the burden of proof, we are justified in condemning a proposed rate, protested as too low, if the carriers which sponsor it do not sufficiently show that it will cause gain rather than loss. But our authority, in our opinion, goes further. We are justified in condemning a proposed rate as too low if the evidence warrants the conclusion that it will, because of its lowness, tend to precipitate changes in rate structure or in traffic which will be harmful to the public interest, having in mind our responsibility for railroad earnings in general under section $15{ }^{4} .{ }^{42}$

Again, in Gasoline from San Francisco Bay Points to Ogden, Utah, the Commission said with reference to two decisions of the Federal courts:

The broad purpose of and the ultimate responsibilities imposed upon us by both the old and the new section $15 \mathrm{a}(2)$ are the same, namely, in prescribing rates to give "due consideration ... to the need of revenues sufficient to enable the carriers, under honest,

${ }^{10}$ East St. Louis Cotton Oil Co. v. Baltimore \& O. R. R., 243 I.C.C. 43, 46 (r940); Petroleum from South Atlantic Ports to Southeast, 244 I.C.C. 23, 29 (r94I); Macaroni between Western Trunk-Line and Southwestern Territories, 238 I.C.C. 121, 124 (1940); Express Merchandise from Cincinnati to South, 210 I.C.C. 89, 93 (1935); Lake and Rail Class and Commodity Rates, 214 I.C.C. 93, 1 18 (1936); Atlantic City Coal Dealers Credit Bureau v. Atlantic City R. R., 209 I.C.C. 737, 74I (1935).

${ }^{11}$ Ex-Lake Iron Ore from Chicago to Granite City, 123 I.C.C. 503,504 (1927); Salt Cases of 1923, 92 I.C.C. 388 , 4 ro (1924); Coal from Indiana to Illinois, 197 I.C.C. 245 (1933); 200 1.C.C. 609, 621 (1934); Sugar from New Orleans to Arkansas, 243 I.C.C. 703, 708 (I94I).

4 123 I.C.C. 503, 5C4 (1927). 
economical, and efficient management, to provide . . . adequate and efficient railway transportation service." See United States v. Louisiana, 290 U. S. 70.

In Jefferson Island Salt Mining Company v. United States, 6 Fed. (2d) 315, referring to the enlarged powers conferred upon us by amended sections 13,15 and 15 a, the Court said:

"By these sections the Commission is now empowered to raise the rates, not merely because noncompensatory to the carrier receiving them, but because they are unjust or unreasonable from the point of view of other carriers and localities."

In Anchor Coal Company v. United States, 25 Fed. (2d) 462, 47 $\mathrm{r}$, the following appears:

"Of course, since the passage of the Transportation Act of 1920 the Commission has the right to prescribe minimum rates, and we agree with the Commission that a construction of the law is too narrow which limits its right to prescribe such rates to cases where the rates proposed are unreasonable per se, or are so low as to cast a burden on other traffic. It has the right to prescribe minimum rates also to prevent ruinous rate wars and to guarantee reasonable earnings, not only to the carrier affected but also to competing carriers, who may labor under a higher cost of doing business." 43

The Commission further expounded the law on this subject in its report in Coke from Southern Points to Southern Ports, in the following language:

It is obviously our duty to prevent rate wars between competing carriers, under which they reduce rates below a reasonable basis in an effort to capture traffic handled by their competitors and are met by corresponding reductions calculated to hold the traffic to the lines of the carriers already handling it. Eventually we could end such a rate war under Section I of the Act by permitting retaliatory reductions until one or the other rate became per se unreasonably low. If this course were followed, certain shippers temporarily would obtain the advantage of rates below a reasonable basis, but the shipping public would eventually foot the bill, either through increased rates on other traffic or deterioration of service. ....44

From the foregoing unanimous course of authority, as well as the plain and obvious policy embodied in the Interstate Commerce Act, it is clear that no shipper, state, or section is unlawfully discriminated against, or in any other way deprived of any legal right, by the fact that the rate conferences may in certain instances have a tendency to discourage rate reductions which the forces of competition might otherwise bring about, but which would have a destructive effect on the revenues of the railroads.

The interest of the South in the destruction of the rate conferences is being enlisted on the representation that if in some way the restrictions of the Interstate Commerce Act could be nullified, and railroad rates thrown open to the free play of competition, reductions would result in those higher northbound interterritorial rates of which the South complains, and southern shippers would thereby be advantaged. The argument rests upon the contention that it would be to the interest of the South if the rate structure of the country were more flexible and fluid, and more responsive than it is, under regulation, to the sudden and multiple changes that

4s 198 I.C.C. 683,697 (1934).

¿204 I.C.C. 767,773 (1934). 
would result if the railroads constantly lowered their rates to take business away from one another. I venture to suggest that nothing would be more disadvantageous than this to the South, or more effective in defeating its attainment of the advantageous rate relationships which it desires with other sections of the country. Presumably and purportedly, what the South desires is a stable rate relationship of equality with the North. Such a desire cannot be gratified without reasonable stability in the rate structure, since what the South seeks is assurance that the desired rate relationship will be maintained with some degree of permanence.

Nothing could more effectively frustrate the demands of the South in this respect than for the philosophy of a fluid rate structure to triumph over the philosophy of regulation embodied in the Interstate Commerce Act. If the former philosophy should supersede the latter as the basis of our transportation law, the hope of any stable relationship between southern and northern rates would become an empty dream. If rate relationships were to be made a plaything of the unrestricted forces of competition, and were cut loose from the regulatory restrictions and voluntary procedures which give to them the degree of stability that they now have, there would be no way whatever by which the South could be assured that her rates would bear the relationship that she desires to the northern rate level, or any certain relationship whatever. On the contrary, the forces of unrestricted competition not only might, but almost certainly would, drive down rates in the North to levels below those which the same forces would produce in the South. If this were so, the South would no longer have any recourse in effective regulation by which to redress the balance. The South should, therefore, realize that its hope of obtaining the level of rates which it professes to desire lies in the continuance of the effective restraints on competitive rate making which are embodied in the Interstate Commerce Act. It has been my purpose in this paper to show that the existence and operation of the rate conferences are not only in exact accord with the policy of those regulatory restraints, but are essential to make them effective. 